\title{
Aspek Reproduksi Ikan Betutu (Oxyeleotris marmorata Blkr.) yang Tertangkap di Waduk Penjalin Brebes
}

\author{
Azizah Nur Fatimah*, Sugiharto, Nuning Setyaningrum
}

\author{
Fakultas Biologi, Universitas Jenderal Soedirman \\ Jalan dr. Suparno 63 Purwokerto 53122 \\ *Email: azizahnur0329@gmail.com
}

Rekam Jejak Artikel:

Diterima : 28/08/2019

Disetujui : 30/10/2019

\begin{abstract}
Betutu (Oxyeleotris marmorata Blkr.) is a wild freshwater fish in the Penjalin reservoir. The purposes of this study are to find out the reproductive aspects of the betutu in the Penjalin reservoir and find out the long and heavy relationship to the Gonado Somatic Index (GSI) and Stage of Gonad Mature (SGM). The method used is a survey with sampling taken by using purposive sampling at 5 stations. The parameters measured were body length and weight, gonad weight, and weight, number of eggs, diameter egg, number of fish, while the supporting parameters were water quality consisting of temperature, light penetration, water depth, $\mathrm{pH}$, Dissolved Oxygen, Total Dissolved Solid (TDS), and Biological Oxygen Demand (BOD). The results of this study indicate that the overall sex ratio of male and female fish is 1.05: 2.15. The fecundity of eggs caught is 9,270 eggs with egg diameters between $0.26-0.56 \mathrm{~mm}$. Betutu caught have SGM I to SGM III with the dominance of SGM I. The Gonado Somatic Index (GSI) of male betutu is relatively smaller between $0.0087 \%-0.514 \%$ compared to female betutu between $0.0165 \%-1.4205 \%$. The greater IKG will affect the value of the Hepatosomatic Index which will increase until just before the fish spawn. The HSI value of betutu obtained was $0.2477 \%$ $4.0761 \%$ in female and in male $0.4065 \%-5.1364 \%$. The results of the analysis on the relationship of length, fish bodyweight towards the gonad maturity index produced a close relationship, but there was no relation between the length, weight of the fish body to the level of gonadal maturity.
\end{abstract}

Keywords: Oxyeleotris marmorata, reproduction, Penjalin, gonad

\section{Abstrak}

Ikan betutu (Oxyeleotris marmorata Blkr.) merupakan ikan air tawar liar di Waduk Penjalin. Tujuan dari penelitian ini yaitu untuk mengetahui aspek reproduksi ikan betutu di Waduk Penjalin dan mengetahui hubungan panjang dan berat terhadap IKG dan TKG. Metode yang digunakan yaitu survey dengan pengambilan sampel dilakukan secara purposive sampling pada 5 stasiun. Parameter yang diukur yaitu panjang dan berat tubuh, berat gonad, berat hati, jumlah telur, diameter telur, jumlah ikan, sedangkan parameter pendukungnya yaitu kualitas air yang terdiri dari suhu, penetrasi cahaya, kedalaman air, $\mathrm{pH}$, oksigen terlarut (Dissolved Oxygen), TDS (Total Dissolved Solid), dan BOD (Biologycal Oxygen Demand). Hasil peneitian ini menunjukkan bahwa rasio kelamin ikan jantan dan ikan betina secara keseluruhan 1,05:2,15. Fekunditas telur ikan betutu yang tertangkap sebanyak 9.270 butir dengan diameter telur antara 0,26-0,56 mm. Ikan betutu yang tertangkap memiliki TKG I sampai TKG III dengan dominasi TKG I. Indeks kematangan gonad (IKG) ikan betutu jantan relatif lebih kecil antara 0,0087 \% $0,514 \%$ dibandingkan ikan betutu betina antara $0,0165 \%-1,4205 \%$. IKG semakin besar mempengaruhi nilai Indeks Hepatosomatik yang semakin besar sampai sesaat sebelum ikan memijah. Nilai IHS ikan betutu yang diperoleh yaitu $0,2477 \%-4,0761 \%$ pada ikan betina dan pada ikan jantan $0,4065 \%-5,1364 \%$. Hasil analisis terhadap hubungan panjang, berat tubuh ikan terhadap indeks kematangan gonad menghasilkan hubungan yang erat, namun tidak ada hubungan antara panjang, berat tubuh ikan terhadap tingkat kematangan gonad.

Kata kunci : Oxyeleotris marmorata, reproduksi, Waduk Penjalin, gonad. 


\section{PENDAHULUAN}

Waduk Penjalin merupakan salah satu waduk yang ada di Jawa Tengah. Waduk ini terletak di Desa Winduaji, Kecamatan Paguyangan, Kabupaten Brebes. Ikan betutu (Oxyeleotris marmorata) merupakan ikan air tawar yang hidup di sungai, waduk, dan rawa (Fatah \& Adjie, 2013), merupakan ikan karnivora yang dapat memangsa ikan kecil, krustase, dan insekta (Razi, 2014). Ikan betutu memiliki ketahanan yang cukup tinggi terhadap salinitas dan bahkan dapat hidup di air payau (Chew et al., 2009). Ikan tersebut dapat mendominasi di perairan waduk apabila tidak ada kompetisi dengan predator lain (Hedianto et al., 2013). Dominasi ikan ini akan membahayakan bagi ikan lainnya yang ada di perairan yang sama. Hal ini yang mendasari dilakukan penelitian untuk mengetahui aspek reproduksi ikan betutu di waduk penjalin.

Aspek reproduksi ikan penting dipelajari karena digunakan untuk mengetahui siklus hidupnya. Aspek reproduksi ikan terdiri dari fekunditas, diameter telur, tingkat kematangan gonad (TKG), dan indeks kematangan gonad (IKG) (Fatah \& Adjie, 2013). Fekunditas merupakan jumlah telur yang ada di dalam gonad (Effendie, 1979). Kematangan gonad ikan merupakan tingkatan perkembangan gonad sebelum dan sesudah ikan memijah (Utiah, 2007). TKG juga dapat digunakan untuk memprediksi status reproduksi ikan dan ukuran pertama kali ikan memijah (Fatah \& Adjie, 2013). Indeks kematangan gonad (IKG) merupakan nilai presentase dari TKG yang dibandingkan dengan panjang tubuh ikan. Hubungan panjang berat ikan berperan penting dalam aspek biologi, yaitu waktu awal kematangan dan pemijahan (Aryani et al., 2016). Mengetahui rasio kelamin ikan penting untuk memperoleh perbandingan jumlah ikan jantan dan ikan betina, sehingga dapat memprediksi kelestarian populasi ikan di suatu tempat pada masa yang akan datang (Saputra et al., 2009). Dengan demikian perlu dikaji tentang aspek reproduksi ikan Betutu meliputi fekunditas, diameter telur, tingkat kematangan gonad, indeks kematangan gonad, indeks hepatosomatic, dan rasio kelamin serta hubungannya dengan Panjang tubuh dan berat tubuh.
Sumber air waduk ini berasal dari tiga sungai di sekitarnya yaitu sungai soka, penjalin, dan garung. Waduk ini digunakan untuk kegiatan pertanian, perikanan, dan sebagainya (Elinah et al., 2016)

\section{MATERI DAN METODE}

Penelitian ini dilakukan di Waduk Penjalin dan Laboratorium Biologi Akuatik Fakultas Biologi Universitas Jenderal Soedirman Purwokerto. Penelitian ini dilakukan dari bulan April, Mei, Agustus, dan September 2018. Metode penelitian yang digunakan yaitu metode survey dan pengambilan sampel dilakukan secara purposive random pada 5 stasiun. Langkahlangkah yang dilakukan yaitu: Pengambilan sampel ikan dilakukan menggunakan jaring ikan (Sitepu et al., 2018) ukuran $60 \mathrm{~m} \times 1,5 \mathrm{~m}$. Jaring ikan tersebut ditebar di waduk pada pukul 17.00 dan ditunggu semalam untuk diambil pukul 05.00 pagi.

Aspek reproduksi yang diamati antara lain:

a. Fekunditas

Fekunditas ikan dihitung menggunakan metode gravimetri (Effendie, 1979), dengan rumus:

$$
\begin{aligned}
& \mathrm{F}=\frac{G \cdot x}{g} \\
& \text { Keterangan: } \\
& \mathrm{F} \quad \text { : fekunditas } \\
& \mathrm{G} \quad \text { : berat gonad total }(\mathrm{g}) \\
& \mathrm{g} \quad \text { : berat gonad sampel }(\mathrm{g}) \\
& \mathrm{X} \quad \text { : jumlah telur sampel (butir) }
\end{aligned}
$$

\section{b. Diameter Telur}

Diameter telur matang diukur dengan menggunakan mikrometer objektif dan mikrometer okuler dengan mikroskop cahaya. Sampel telur diambil dari bagian anterior, median, dan posterior ovarium. Diemeter telur diukur dari sisi diameter vertikal dan horizontal. Diameter telur dihitung dengan rumus (Unus \& Omar, 2010):

Ds $=\sqrt{D x d}$

\begin{tabular}{|c|c|c|}
\hline TKG & Betina & Jantan \\
\hline I & $\begin{array}{l}\text { Ovari seperti benang, panjang sampai ke depan rongga } \\
\text { tubuh. Warna jernih. Permukaan licin. }\end{array}$ & $\begin{array}{l}\text { Testis seperti benang, lebih terbatas dan terlihat } \\
\text { ujungnya di rongga tubuh. Berwarna jernih. }\end{array}$ \\
\hline II & $\begin{array}{l}\text { Ukuran ovari lebih besar. Berwarna lebih gelap } \\
\text { kekuning-kuningan. Telur belum terlihat jelas dengan } \\
\text { mata. }\end{array}$ & $\begin{array}{l}\text { Ukuran testis lebih besar. Berwarna putih seperti } \\
\text { susu. Bentuk lebih jelas daripada tingkat I. }\end{array}$ \\
\hline III & $\begin{array}{l}\text { Ovari berwarna kuning. Secara morfologi, butir telur } \\
\text { mulai terlihat. }\end{array}$ & $\begin{array}{l}\text { Permukaan testis tampak bergerigi dan bentuknya } \\
\text { semakin besar. Warna semakin putih. Dalam keadaan } \\
\text { diawetkan mudah putus. }\end{array}$ \\
\hline IV & $\begin{array}{l}\text { Ovari semakin besar, telur berwarna kuning, dan mudah } \\
\text { dipisahkan. Butir minyak tidak tampak. Mengisi 1/2-2/3 } \\
\text { rongga perut sehingga saluran pencernaan terdesak. }\end{array}$ & $\begin{array}{l}\text { Seperti pada tingkat III tetapi tampak lebih jelas dan } \\
\text { testis semakin pejal. }\end{array}$ \\
\hline V & $\begin{array}{l}\text { Ovari berkerut, dinding tebal, tersisa butir telur di dekat } \\
\text { dinding, banyak telur seperti pada tingkat II. }\end{array}$ & $\begin{array}{l}\text { Testis bagian belakang mengkerut tetapi di bagian } \\
\text { dekat pelepasan masih berisi. }\end{array}$ \\
\hline
\end{tabular}

Keterangan:

Ds : Diameter telur sebenarnya $(\mathrm{mm})$

D : Diameter telur secara horizontal $(\mathrm{mm})$

d : Diameter telur secara vertikal $(\mathrm{mm})$

Tabel 1. Tingkat Kematangan Gonad Ikan menurut Effendie (1979) 


\section{c. Tingkat Kematangan Gonad (TKG)}

Tingkat kematangan gonad diamati secara morfologi, seperti pada Tabel 1. dengan melihat warna, bentuk, ukuran panjang dan berat, serta perkembangan isi gonad.

d. Perhitungan Indeks Kematangan Gonad (IKG) Indeks kematangan gonad ditentukan dengan membandingkan berat gonad dengan berat tubuh (Effendie, 1979) yaitu:

$$
\begin{aligned}
& \mathrm{IKG}=\frac{B g}{B t} \times 100 \% \\
& \text { Keterangan : } \\
& \mathrm{IKG}: \text { indeks kematangan gonad } \\
& \mathrm{Bg}: \text { berat gonad }(\mathrm{g}) \\
& \mathrm{Bt}: \text { berat ikan }(\mathrm{g})
\end{aligned}
$$

\section{e. Indeks hepatosomatik (IHS)}

Indeks hepatosomatik (IHS) dihitung dengan membandingkan berat hati dengan berat tubuh ikan menurut Htun-Han (1978) dengan rumus sebagai berikut:

$$
\begin{aligned}
& \text { IHS }=\frac{B h}{B t} \mathrm{x} 100 \% \\
& \text { Keterangan: } \\
& \text { IHS: indeks hepatosomatik } \\
& \text { Bh : berat hati }(\mathrm{g}) \\
& \text { Bt : berat tubuh }(\mathrm{g})
\end{aligned}
$$

\section{f. Rasio Kelamin}

Rasio kelamin dihitung dengan membandingkan jumlah ikan jantan dan jumlah ikan betina (Haryani, 1998) yang tertangkap dengan rumus sebagai berikut:

$$
\begin{aligned}
& \text { Rasio kelamin }=\mathrm{J} / \mathrm{B} \\
& \text { Keterangan: } \\
& \mathrm{J} \quad \text { : jumlah ikan jantan (ekor) } \\
& \mathrm{B} \quad \text { : jumlah ikan betina (ekor) }
\end{aligned}
$$

\section{g. Penentuan Jenis Gonad}

Penentuan jenis gonad dilakukan menggunakan metode squash (pencet) (Galigher \& Kozloff, 1971). Langkah pertama yaitu dengan mengambil sampel gonad yang akan diamati, kemudian dipotong sekitar $3 \mathrm{~mm}$ serta diletakkan di gelas objek dan ditutup dengan gelas penutup. Gonad tersebut kemudian di pencet pelan-pelan, setelah itu ditetesi acetocarmine sebanyak 1-2 tetes (Jones, 1950). Preparat gonad siap untuk diamati menggunakan mikroskop untuk menentukan apakah gonad tersebut testis atau ovarium. Apabila gonad tersebut ovarium maka akan terlihat gelembunggelembung lemak yang didalamnya terdapat butiran-butiran dengan diameter bervariasi, dan transparan. Namun, apabila gonad tersebut testis maka akan tampak butiran-butiran halus dan seragam (Helmizuryani et al., 2017). Aspek reproduksi dianalisis secara deskriptif. Hubungan panjang, berat terhadap tingkat kematangan gonad dan indeks kematangan gonad dianalisis secara korelasi.

\section{HASIL DAN PEMBAHASAN \\ Rasio Kelamin}

Secara keseluruhan terdapat 21 ekor ikan jantan dan 43 ekor ikan betina, sehingga diperoleh rasio kelamin jantan dan betina 1,05: 2,15. Berdasarkan hasil tersebut, ikan betutu yang tertangkap di waduk penjalin secara keseluruhan memiliki jumlah ikan betina yang lebih banyak daripada ikan jantan. Menurut Effendie (2002), rasio kelamin ideal antara ikan jantan dan betina yaitu 1:1 atau jumlah betina yang lebih banyak. Apabila populasi ikan betina lebih banyak (misal 1:2), maka populasi ikan tersebut di alam dapat dipertahankan karena saat pemijahan terjadi satu ikan jantan akan memperoleh pasangan beberapa betina. Namun sebaliknya, apabila populasi jantan lebih banyak maka populasi ikan di alam perlu diperhatikan lagi karena saat terjadi pemijahan maka ikan jantan akan sulit memperoleh pasangannya. Menurut Rahman et al. (2013) perbandingan jumlah ikan jantan dan betina di alam tidaklah mutlak karena masih dipengaruhi oleh keadaan lingkungan. Keadaan tersebut dapat dipengaruhi oleh perbedaan pola tingkah laku, pertumbuhan, dan laju mortalitas ikan jantan dan betina (Sitepu et al., 2018).

\section{Fekunditas dan Diameter Telur}

Fekunditas ikan betutu di waduk Penjalin ini sebanyak 9.720 butir telur. Fekunditas yang diperoleh sudah pada tingkat kematangan gonad III. Fekunditas erat hubungannya dengan diameter telur ikan. Diameter telur ikan betutu bagian anterior berkisar antara 0,26$0,55 \mathrm{~mm}$, median $0,34-0,56 \mathrm{~mm}$, dan posterior $0,3-0,38$ $\mathrm{mm}$ (Tabel 2).

Tabel 2. Fekunditas dan Diameter Telur Ikan Betutu yang Tertangkap di Waduk Penjalin

\begin{tabular}{cccccc} 
Berat & Panjang & Fekundit & \multicolumn{3}{c}{ Diameter Telur $(\mathrm{mm})$} \\
\cline { 4 - 6 }$(\mathrm{gr})$ & $\begin{array}{c}\text { Tubuh } \\
(\mathrm{cm})\end{array}$ & $\begin{array}{c}\text { as } \\
\text { (butir) }\end{array}$ & $\begin{array}{c}\text { Anterio } \\
\mathrm{r}\end{array}$ & Median & Posterior \\
\hline \multirow{2}{*}{150} & 22,7 & 9.720 & $0,56-$ & $0,34-$ & $0,3-$ \\
& & & 0,56 & 0,38
\end{tabular}

Secara keseluruhan diameter telur ikan betutu pada TKG III berkisar antara 0,26-0,56 mm.Fekunditas yang diperoleh mencapai 9.720 butir. Hasil ini menunjukkan bahwa fekunditas ikan betutu yang ditemukan cukup besar. Hal ini karena ikan betutu merupakan ikan yang memiliki kisaran fekunditas yang lebar, dalam satu periode pemijahannya dapat mencapai ribuan hingga puluhan ribu telur. Menurut Tavarutmaneegul \& Lin (1988), kisaran fekunditas ikan betutu di Thailand dapat mencapai 2.000 hingga 30.000 butir pada ikan dengan kisaran bobot tubuh 300-500 g. Puncak pemijahan ini terjadi pada bulan Mei dan Juni, selain itu menurut Fatah \& Adjie (2013) fekunditas ikan betutu mencapai antara 6.414 sampai 56.302 butir dengan puncak pemijahan pada bulan Oktober.

Menurut Harianti (2013), fekunditas ikan dapat dipengaruhi beberapa faktor antara lain, umur, ukuran, spesies, dan kondisi lingkungan, serta pakan. Semakin bertambah ukuran tubuh ikan seperti panjang dan bobot tubuh secara linear akan menambah fekunditas ikan. 
Fekunditas tiap spesies ikan akan berubah seiring berubahnya keadaan lingkungan, seperti kepadatan populasi ikan di lingkungan tersebut dan ketersediaan pakan (Effendie, 1997). Selanjutnya, Unus dan Omar (2010), mengatakan ketersediaan pakan yang banyak dan sesuai dengan kebutuhan ikan tersebut akan meningkatkan pertumbuhan ikan menjadi cepat dan semakin menambah fekunditas pula.

Diameter telur memiliki hubungan erat dengan fekunditas. Semakin besar nilai fekunditas, semakin kecil pula ukuran diameter telur. Besar kecilnya ukuran telur, berkaitan dengan jumlah kuning telur atau cadangan makanan yang ada. Semakin besar ukuran telur, maka semakin besar cadangan makanan yang ada di dalam telur tersebut (Unus \& Omar, 2010). Besarnya ukuran telur ini selain dari hasil akumulasi kuning telur (cadangan makanan) juga dari hasil hidrasi dan pembentukan butiran-butiran minyak di dalamnya (Effendie, 1997). Kualitas telur juga dipengaruhi oleh faktor internal dan eksternal. Faktor internal berupa umur induk, ukuran induk, dan genetik. Faktor eksternal terdiri dari pakan, suhu, cahaya, kepadatan, dan populasi (Fani et al., 2015).

\section{Tingkat Kematangan Gonad}

Secara keseluruhan dari bulan April, Mei, Agustus dan September ikan betutu di waduk Penjalin yang tertangkap yaitu TKG I-TKG III dengan panjang tubuh antara 12-118,4 cm. Namun, semakin bertambah panjang ikan betutu tidak menjamin bahwa TKG akan semakin meningkat, karena pada panjang $22,7 \mathrm{~cm}$ (Tabel 1) sudah mencapai TKG III.

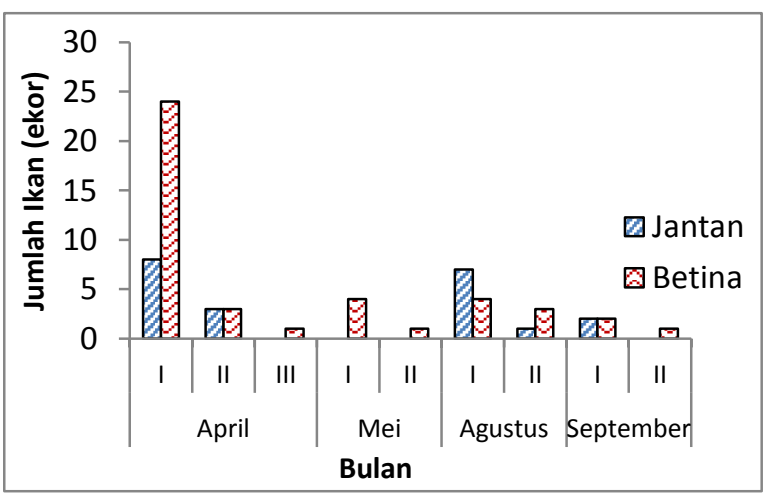

Gambar 1. Tingkat Kematangan Gonad Ikan Betutu yang Tertangkap di Waduk Penjalin
Tingkat Kematangan Gonad ikan betutu yang didapat sebagian besar termasuk dalam TKG I, hal ini dapat dikatakan bahwa ikan betutu yang tertangkap masih dalam usia/umur muda atau belum matang gonad. Hal ini dapat disebabkan karena puncak pemijahan ikan betutu yaitu pada musim penghujan awal (Komarudin, 2000) yaitu pada bulan Oktober, sehingga ikan yang ditemukan pada bulan April sampai September pada penelitian tidak banyak ditemukan yang matang gonad. Hal ini sesuai dengan pernyataan Fatah \& Adjie (2013), bahwa puncak pemijahan ikan betutu pada bulan Oktober. Namun, pada penelitian ini juga ditemukan 1 ekor ikan yang matang gonad (TKG III) pada bulan April. Hal ini sesuai dengan penelitian Sitepu et al. (2018) bahwa ikan betutu mengalami matang gonad dominan pada bulan April. Perbedaan kematangan gonad tersebut dipengaruhi oleh beberapa faktor yaitu faktor dari dalam dan dari luar. Faktor dalam terdiri dari, spesies, umur, ukuran tubuh, dan sifat fisiologis individu, sedangkan faktor luar terdiri dari suhu, pakan, dan arus (Larger et al., 1977).

\section{Indeks Kematangan Gonad}

Selama penelitian ini, didapat nilai IKG yang bervariasi, nilai IKG ikan betutu jantan relatif lebih kecil antara $0,0087 \%-0,514 \%$ dibandingkan ikan betutu betina antara $0,0165 \%-1,4205 \%$ (Tabel 3). Berdasarkan hasil penelitian tersebut, diperoleh nilai IKG pada TKG III dengan nilai $0,52 \%$, sedangkan pada TKG II sebesar 1,4205\% (Tabel 3.). Semakin tinggi TKG maka akan semakin tinggi pulai nilai IKG. Hal ini kemungkinan karena ikan pada TKG III merupakan ikan yang sudah berkali-kali matang gonad (memijah) sehingga cenderung menghasilkan kualitas dan kuantitas ovarium yang lebih baik daripada ikan yang baru pertama kali memijah (Siby et al., 2009).

Menurut Sulistiono et al. (2001), bahwa umumnya nilai IKG ikan betina lebih besar dari ikan jantan. Nilai IKG meningkat seiring meningkatnya volume oosit (Fani et al., 2015). Nilai IKG sangat bervariasi pada tiap individu karena berkaitan dengan berat gonad dan berat tubuh yang bergantung pada kondisi tiap individu, status kematangan gonad, dan kondisi lingkungan. Indeks Kematangan Gonad ini mencapai nilai tertinggi sesaat menjelang pemijahan (Ozvarol et al., 2010), saat akan memijah berat gonad akan semakin besar, namun berat tubuh akan semakin

Tabel 3. Indeks Kematangan Gonad Ikan Betutu

\begin{tabular}{ccccccc}
\hline \multirow{2}{*}{ No } & \multirow{2}{*}{ Bulan } & \multirow{2}{*}{ TKG } & \multicolumn{2}{c}{ Frekuensi } & \multicolumn{2}{c}{ IKG (\%) } \\
\cline { 3 - 7 } & & & Jantan & Betina & Jantan & Betina \\
\hline \multirow{2}{*}{ April } & I & 8 & 24 & $0,0182-0,0327$ & $0,0111-0,2298$ \\
& & II & 3 & 3 & $0,0087-0,0203$ & $0,2231-0,2286$ \\
& & III & - & 1 & - & 0,52 \\
2 & \multirow{2}{*}{ Mei } & I & - & 4 & - & $0,0165-0,3$ \\
& & II & - & 1 & - & 0,4228 \\
3 & \multirow{2}{*}{ Agustus } & I & 7 & 4 & $0,0199-0,5144$ & $0,0181-0,2312$ \\
& & II & 1 & 3 & 0,0175 & $0,923-1,4205$ \\
\multirow{2}{*}{4} & September & I & 2 & 2 & $0,0185-0,0222$ & $0,1932-0,7455$ \\
& & II & - & 1 & - & 0,2357 \\
\hline
\end{tabular}


menurun terkait cadangan energi dalam tubuh digunakan untuk perkembangan gonad (Yoneda et al., 2013). Menurut Effendie (2002), nilai IKG dapat digunakan untuk mengetahui kapan waktu ikan memijah. Berat gonad maksimum terjadi sesaat sebelum memijah dan menurun dengan cepat selama pemijahan berlangsung sampai selesai.

\section{Indeks Hepatosomatik}

Nilai IHS ikan betutu pada bulan April Mei, Agustus dan September secara keseluruhan pada ikan betina yaitu antara 0,2477-4,0761 lebih besar daripada ikan jantan (0,4065-5,1364), kecuali pada bulan Agustus ikan jantan mencapai 5,1364 (Tabel 4.)

Tabel 4. Indeks Hepatosomatik Ikan Betutu

\begin{tabular}{lllc}
\hline \multirow{2}{*}{ No } & \multirow{2}{*}{ Bulan } & \multicolumn{2}{c}{ Indeks Hepatosomatik } \\
\cline { 3 - 4 } & & Jantan & Betina \\
\hline 1 & April & $0,4065-1,3089$ & $0,4074-1,8903$ \\
2 & Mei & - & $0,2477-1,8794$ \\
3 & Agustus & $0,7895-5,1364$ & $1,0127-4,0761$ \\
4 & September & $0,9556-1,2778$ & $0,7727-3,3181$ \\
\hline
\end{tabular}

Hati merupakan organ biomarker yang digunakan sebagai indikator kesehatan ikan dan gambaran terhadap paparan polutan antropogenik. Indeks Hepatosomatik merupakan presentase perbandingan antara berat hati dengan berat tubuh yang menggambarkan proses metabolisme di hati (Sadekarpawar \& Parikh, 2013). Berat tubuh ikan akan berangsur turun terjadi ketika proses pematangan gonad. Proses perkembangan gonad (vitellogenesis) akan melibatkan sintesis vitelogenin yang terjadi di hati. Sintesis ini dipengaruhi estradiol-17 $\beta$. Nilai IHS ikan akan menurun seiring maturasi gonad. Hal ini karena ikan mengalokasikan pertumbuhan somatiknya untuk reproduksi, konversi energi ini sebagian menggunakan energi cadangan yang ada di hati (Fani et al., 2015).

Proses vitellogenesis yang terganggu juga dapat berdampak pada mengecilnya ukuran telur. Ukuran telur dapat mengecil karena adanya paparan polutan di lingkungan terutama logam berat yang akan mempengaruhi perkembangan kelamin awal dan akhir. Paparan logam berat dapat mengganggu metabolisme hati sehingga akan terjadi penyusutan inti sel yang menyebabkan menurunnya bobot hati (Zulfahmi et al., 2014).

\section{Hubungan Panjang dan Berat Tubuh terhadap Indeks Kematangan Gonad}

Hubungan Panjang dan berat tubuh ikan terhadap IKG dilakukan dengan mencari korelasi keduanya terhadap IKG menggunakan analisis korelasi berganda simultan. Berdasarkan analisis tersebut, dapat diketahui bahwa terdapat adanya hubungan antara panjang tubuh terhadap indeks kematangan gonad. Berdasarkan hasil uji korelasi antara Panjang dan berat terhadap IKG bahwa panjang tubuh berpengaruh erat terhadap indeks kematangan gonad begitupun sebaliknya dengan nilai koefisien korelasi sebesar 0,427 ( $>>0,01)$. Oleh karena itu perlu dilakukan uji lanjut yaitu regresi untuk mengetahui seberapa besar pengaruh Panjang tubuh terhadap indeks kematangan gonad setelah diketahui adanya korelasi, sementara itu berat tubuh terhadap indeks kematangan gonad tidak berpengaruh positif dengan koefisien korelasi $(-0,030)$.

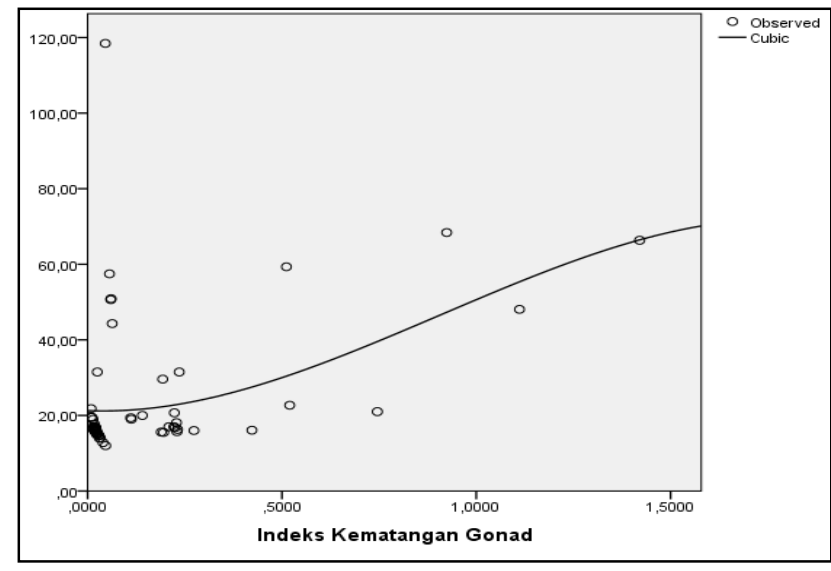

Gambar 2. Kurva Hasil Analisis Regresi Kubik Panjang terhadap Indeks Kematangan Gonad Ikan Betutu

Berdasarkan analisis regresi, diperoleh kurva kubik hubungan panjang tubuh terhadap indeks kematangan gonad dengan koefisien determinasi $\left(\mathrm{R}^{2}\right)$ sebesar $19 \%$. Hal ini menggambarkan bahwa besarnya pengaruh panjang tubuh terhadap indeks kematangan gonad sebesar 19\%. Hubungan panjang dan berat ikan tidak berpengaruh nyata terhadap kematangan gonad karena ukuran ikan yang ditemukan di waduk ini masih kecil sehingga panjang dan berat ikan tidak berpngaruh nyata terhadap perkembangan gonad. Panjang dan berat tubuh ikan mengalami fluktuasi atau perbedaan apabila lingkungannya berbeda. Panjang tubuh ikan bervariasi karena perbedaan letak geografis, habitat, dan tingkah laku (Taringan et al., 2017).

\section{Hubungan Panjang dan Berat Tubuh Ikan Betutu Terhadap Tingkat Kematangan Gonad \\ Hubungan panjang dan berat tubuh ikan betutu} terhadap tingkat kematangan gonad dianalisis menggunakan analisis korelasi berganda simultan, hasil analisis menunjukkan bahwa panjang dan berat tubuh ikan betutu tidak memiliki hubungan yang signifikan terhadap tingkat kematangan gonad. Hal ini karena ikan yang ditemukan masih dominan ikan muda dengan TKG I, walaupun ikan tersebut memiliki panjang dan berat tubuh yang relatif besar, sehingga dua faktor tersebut bukan faktor utama yang mempengaruhi kematangan gonad. Menurut Kordi \& Tamsil (2010), panjang dan berat tubuh ikan tidak dapat ditentukan secara nyata karena panjang dan berat tubuh sangat dipengaruhi faktor lingkungan. Faktor lingkungan yang paling mempengaruhi kematangan gonad yaitu suhu dan makanan. Faktor lain yaitu fotoperiode dan musim terutama di daerah subtropis. Kematangan gonad akan semakin cepat apabila berada di suhu optimum dan penyinaran yang rendah. Perbedaan individu matang gonad disebabkan oleh umur, ukuran, dan faktor fisiologi dari ikan (Taringan et al., 2017). 


\section{SIMPULAN}

Berdasarkan hasil penelitian yang diperoleh, dapat ditarik kesimpulan bahwa Ikan Betutu yang tertangkap di Waduk Penjalin memiliki proporsi jantan dan betina 1:2 dengan kematangan gonad dari TKG I sampai TKG III, serta memiliki fekunditas sebesar 9.720 butir dengan kisaran diameter telur yang luas antara 0,26-0,55 mm. Secara keseluruhan nilai IHS ikan betina lebih besar dari ikan janta. Panjang tubuh ikan betutu memiliki hubungan yang erat terhadap indeks kematangan gonad, sedangkan tidak ada hubungan antara panjang dan berat tubuh ikan terhadap tingkat kematangan gonad

\section{UCAPAN TERIMA KASIH}

Terima kasih pula kepada BLU Unsoed yang telah berkontribusi memberikan dana selama penelitian serta semua pihak yang telah berkontribusi dalam penelitian ini.

\section{DAFTAR REFERENSI}

Aryani, N., Suharman, I., \& Hasibuan, S., 2016. Lengthweight relationship and condition factor of the critically endangered fish of Geso, Hemibagrus wyckii (Bleeker, 1858) bagridae from Kampar Kanan River, Indonesia. Journal of Entomology and Zoology Studies. 4 (2), pp. 119-122.

Chew, S.F., Tng, Y., Wee, N., Wilson, J.M., \& Yuen., 2009. Nitrogen Metabolism and Branchial Osmoregulatory Acclimation in The Juvenile Marble Goby, Oxyeleotris marmorata, exposed to seawater. Comparative Biochemistry and Physiology. 154, pp. 360-369.

Effendie, M. I., 1979. Metode Biologi Perikanan. Yogyakarta: Yayasan Pustaka Nusatama.

Effendie, M.I., 1997. Biologi Perikanan. Yogyakarta: Yayasan Pustaka Nusatama.

Effendie, M. I., 2002. Biologi Perikanan. Yogyakarta: Yayasan Pustaka Nusatama.

Elinah., Batu, D.T., \& Ernawati, Y., 2016. Kebiasaan Makan dan Luas Relung Ikan-Ikan Indigenous yang Ditemukan di Waduk Penjalin Kabupaten Brebes, Jawa Tengah. Jurnal Ilmu Pertanian Indonesia. 21(2), pp. 98-103.

Fani, A.R., Bijaksana, U., \& Murjani, A., 2015. Intervensi Folicle Stimulating Hormone (Fsh) Dalam Proses Rematurasi Induk Ikan Gabus Haruan Channa striata Blkr Didalam Wadah Budidaya. Fish Scientiae. 5(9), pp. 1-14.

Fatah, K \& Adjie, S., 2013. Biologi Reproduksi Ikan Betutu (Oxyeleotris marmorata) di Waduk Kedung Ombo Propinsi Jawa Tengah. BAWAL. 5(2), pp. 89-96.

Galigher, A.E \& Kozloff, E., 1971. Essentials of Practical Microtechnique Second Edition. London: Great Britain by Henry Kimpton Publishers.
Harianti., 2013. Fekunditas dan Diameter Telur Ikan Gabus (Channa striata Bloch, 1793) di Danau Tempe, Kabupaten Wajo. Jurnal Saintek Perikanan, 8(2), pp. 18-24.

Haryani, G.S., 1998. Analisa Histologi Gonad Ikan-Ikan di Perairan Danau Semayang Kalimantan Timur. Hasil Penelitian Puslitbang Limnologi LIPI Cibinong 1997/1998. pp. 632-637.

Hedianto, D.A., Purnomo, K., \& Warsa, A., 2013. Interaksi Pemanfaatan Pakan Alami Oleh Komunitas Ikan di Waduk Penjalin, Jawa Tengah. BAWAL. 5(1), pp. 33-40.

Helmizuryani., Muslimin, B., \& Khotimah, K., 2017. Pembetinaan Ikan Betok, Anabas testudineus (Bloch, 1792) menggunakan Larutan Susu dan Kedelai melalui Perendaman Larva. Jurnal Ikhtiologi Indonesia. 17(2), pp. 123-132.

Htun-han, M., 1978. The Reproductive Biology of the dab Limanda limanda $(L)$ in the North Sea; Gonadosomatic Index; Hepatosomatic Index and Condition Factor. Journal of Fish Biology, 13(3), pp. 369-378.

Jones, R.M., 1950. McClung's Handbook of Microscopical Technique Third Edition. New York: Hafner Publishing Company.

Komarudin, U., 2000. Betutu: Pemijahan Secara Alami dan Induksi, Pembesaran, di Kolam Keramba dan Hampang. Jakarta: Penebar Swadaya.

Kordi, M.G \& Tamsil, A., 2010. Pembenihan Ikan Laut Ekonomis secara Buatan. Yogyakarta: ANDI.

Lagler, K.F., Bardach, J.E., Miller, R.H., \& Passino, D.M., 1977. Ichthyology. Canada: John Willey \& Sons, Inc.

Ozvarol, Z.A.B., Balci, B.A., Tasli, M.G.A., Kaya, Y., Pehlivan, M., 2010. Age, Growth, and Reproduction of Goldband Goatfish (Upeneus moluccensis, Bleeker (1855)) from the Gulf of the Antalya (Turkey). Journal of Animal and Veterinary Advances. 9(5), pp. 939-945.

Razi, F., 2014. Teknik Budidaya Ikan Betutu (Oxyeleotris marmorata). Penyuluhan Perikanan, No. 038/Fpp/2014.

Sadekarpawar, S \& Parikh, P., 2013. Gonadosomatic and Hepatosomatic Indices of Freshwater Fish Oreochromis mossambicus in Response to a Plant Nutrient. World Journal of Zoology. 8(1), pp. 110-118.

Saputra, S.W., Soedarsono, P., \& Sulistyawati, G.A., 2009. Beberapa Aspek Biologi Ikan Kuniran (Upeneus spp) di Perairan Demak. Jurnal Saintek Perikanan. 5(1), pp. 1-6.

Siby, L.S., Rahardjo, M.F., \& Sjafei, D.S., 2009. Biologi Reproduksi Ikan Pelangi Merah (Glossolepis incisus, Weber 1907) di Danau Sentani. Jurnal Iktiologi Indonesia, 9(1), pp. 4961.

Sitepu, F.G., Suwarni, S., \& Fatmawaty, F., 2018. Nisbah Kelamin, Tingkat Kematangan Gonad 
dan Indeks Kematangan Gonad Ikan Betutu (Oxyeleotris marmorata Blekeer, 1852). Proceeding Simposium Nasional Kelautan dan Perikanan. 5, pp. 273-282.

Sulistiono., Kurniati, T.H., Riani, E., Watanabe, S., 2001. Kematangan Gonad Beberapa Jenis Ikan Buntal (Tetraodon lunaris, T. fluviatilis, $T$. reticularis) di Perairan Ujung Pangkah, Jawa Timur. Jurnal Iktiologi Indonesia, 1(2), pp. 2530.

Taringan, A., Bakti, D., \& Desrita., 2017. Tangkapan dan Tingkat Kematangan Gonad Ikan Selar Kuning (Selariodes leptolepis) di Perairan Selat Malaka. Acta Aquatica. 4(2), pp. 44-52.

Tatangindatu, F., Kalesaran, O., \& Rompas, R., 2013. Studi Parameter Fisika Kimia Air pada Areal Budidaya Ikan di Danau Tondano, Desa Paleloan, Kabupaten Minahasa. Budidaya Perairan, 1(2), pp. 8-19.

Tavarutmaneegul, P \& Lin, C.K., 1988. Breeding and Rearing of Sand Goby Oxyeleotris marmorata, Blkr. Fry. Aquaculture 69, pp.299-305.

Unus, F \& Omar, A., 2010. Analisis Fekunditas dan Diameter Telur Ikan Malalugis Biru (Decapterus macarellus Cuvier, 1833) di Perairan Kabupaten Banggai Kepulauan, Propinsi Sulawesi Tengah. Jurnal Ilmu Kelautan dan Perikanan. 20(1), pp. 37-43.
Utiah, A., 2007. Penampilan Reproduksi Induk Ikan Baung (Mystus nemurus) dengan Pemberian Pakan Buatan yang Ditambah Asam Lemak N-6 dan N-3 dan dengan Implantasi estradiol-17 B dan Tiroksin. Makalah Laporan Sekolah Pasca Sarjana Institut Pertanian Bogor. 78 hal.

Yoneda, M., Kitano, H., Selvaraj, S., Matsuyama, M., \& Shimizu, A., 2013. Dynamics of Gonadosomatic Index of Fish with Indeterminate Fecundity between Subsequent Egg Batches: Application to Japanese Anchovy Engraulis Japonicus Under Captive Conditions. Marine Biology. 160(10), pp. 2733-2741.

Zulfahmi, I., Affandi, R., Batu, D.T., 2014. Kondisi Biometrik Ikan Nila, Oreochromis niloticus (Linnaeus 1758) yang Terpapar Merkuri. Jurnal Iktiologi Indonesia. 14(1), pp. 37-48.

Zulfahmi, I., Muliari, M., \& Akmal, Y., 2017. Indeks Hepatosomatik dan Histopatologi Hati Ikan Nila (Oreochromis Niloticus Linnaeus 1758) yang Dipapar Limbah Cair Kelapa Sawit. In Prosiding Semdi-Unaya (Seminar Nasional Multi Disiplin Ilmu Unaya). 1, pp. 301-314. 